\title{
DEVOCIÓN, UTILIDAD Y DISTINCIÓN. LA REFORMA DE LAS COFRADÍAS NOVOHISPANAS Y EL CULTO DEL SANTÍSIMO SACRAMENTO, 1750-1820
}

\author{
POR \\ DAVID CARBAJAL LÓPEZ \\ Universidad de Guadalajara-Centro Universitario de los Lagos \\ davidclopez@hotmail.com
}

RESUMEN

En la Nueva España de finales del siglo XVIII, el culto del Santísimo Sacramento se renueva con la creación de las congregaciones de cocheros del viático y del alumbrado y vela del Santísimo. Fundadas en el marco de la reforma de las cofradías en el mundo hispánico, nos muestran las contradicciones de los proyectos de los "ilustrados", quienes reconocen la utilidad de una devoción fundamental para la catolicidad. Asimismo, dan cuenta de la importancia creciente de la visibilidad de las jerarquías sociales tanto para los cofrades como para los reformadores.

PALABRAS CLAVE: Cofradías, reformas borbónicas, Eucaristía, culto, devoción, utilidad pública.

\section{DEVOTION, UTILITY AND DISTINCTION. THE REFORM OF THE CONFRATERNITIES OF NEW SPAIN AND THE CULT OF THE BLESSED SACRAMENT, 1750-1820}

\begin{abstract}
In New Spain in the late XVIII ${ }^{\text {th }}$ century, the cult of the Blessed Sacrament is renewed with the creation of the congregations of coachmen for the viaticum, and of the alumbrado of the Blessed Sacrament. Founded in the middle of the reform of the confraternities in the Hispanic world, they show us the contradictions of the projects of the ilustrados, who recognize the value of this fundamental devotion to Catholicism. They also let us realize the growing importance of the visibility of social hierarchies for both, cofrades and reformers.
\end{abstract}

KEY WORDS: Confraternites, bourbon reforms, eucharist, cult, devotion, public utility.

Recibido/Received $\quad$ 07-08-2011

Aceptado/Accepted 22-09-2014

En la segunda mitad del siglo XVIII y primeras décadas del siglo XIX, el Imperio hispánico fue testigo de diversos proyectos de reforma de las cofradías por parte de la Corona, sus magistrados y fiscales, tanto en sus reinos peninsulares como en los americanos. Sobre tales reformas existen ya importantes estudios que nos han mostrado los diversos aspectos de la crítica que por entonces los "ilustrados" del mundo hispánico hacían a esas congregaciones de fieles, reunidas por lo general para rendir culto a una devoción particular. Se les ponía en cuestión, lo mismo por razones de economía política, al distraer los recursos de los súbditos de la Corona hacia gastos inútiles, que por motivos religiosos, siendo acusadas de promover la superstición y de mantener en sus festividades mezclas peligrosas de lo sagrado y lo profano. ${ }^{1}$ Los

1 Un análisis amplio al respecto en M. ROMERO SAMPER, Las cofradías en el Madrid del siglo XVIII, tesis doctoral, Madrid, 1998, 237 435. Y una síntesis para el caso novohispano Clara GARCíA AYLUARDO, reformadores partían del "excesivo número" de cofradías, y por tanto proyectaban su reducción ya fuera extinguiéndolas o fusionándolas. Mas la reforma se llevó a cabo sobre todo a través de la revisión de las constituciones o reglas, sus documentos normativos fundamentales, que hasta entonces habían sido autorizados sólo por los obispos y ahora debían serlo por los principales tribunales civiles, las audiencias y los consejos. $^{2}$

"Re-formar la Iglesia novohispana", en C. GARCÍA AYLUARDO (coord.), Las reformas borbónicas, 1750-1808, 2010, 262-271.

2 C. GARCÍA AYLUARDO, "El privilegio de pertenecer: Las comunidades de fieles y la crisis de la monarquía católica", en Beatriz Rojas (coord.), Cuerpo político y pluralidad de derechos. Los privilegios de las corporaciones novohispanas, 2007, 85-128. I. ARIAS SAAVEDRA y M-L. LÓPEZ-GUADALUPE MUÑOZ, La represión de la religiosidad popular. Crítica y acción contra las cofradías en la España del siglo XVIII, 2002, 242-243 y 350-351. 
Empero, los ímpetus reformistas no pretendían destruir a las cofradías en su conjunto, y aún más se detenían sobre todo ante dos institutos cofrades en particular: el del Santísimo Sacramento y el de las Benditas Ánimas del Purgatorio. Las cofradías de una y otra devoción fueron consideradas, digámoslo desde ahora, útiles y necesarias, por lo que los reformadores aceptaron su continuación sin oponer demasiadas dificultades. Lo veremos en detalle más adelante, fue así tanto en los reinos peninsulares como en los americanos. Pero además, entre estos últimos, el caso de las cofradías del Santísimo Sacramento en la Nueva España reviste particular interés porque justo en esta época, a partir de 1748 para ser precisos, su instituto empieza a renovarse con la aparición de las congregaciones de cocheros, en su origen variación de las archicofradías sacramentales, especialmente dedicadas a su acompañamiento en procesión. ${ }^{3}$ La segunda mitad del siglo verá así la difusión de esta variante de la devoción sacramental, a la que se agregará en los últimos años del siglo otra novedad, proveniente de la propia Corte de Carlos IV: el alumbrado y vela del Santísimo Sacramento, ${ }^{4}$ cuyos hermanos, como su nombre indica, se dedicaban a orar ante él durante ciertos períodos de tiempo de manera casi cotidiana.

Gracias justamente a que surgieron en pleno período de reformas, podemos contar con fuentes importantes a propósito de estas nuevas devociones eucarísticas novohispanas: los expedientes presentados ante el Consejo de Indias para su autorización y para la confirmación de sus constituciones, en los que podemos encontrarnos tanto los planteamientos de los cofrades como los dictámenes de los fiscales de la Corona y los informes del clero al respecto. En este artículo nos interesa el análisis de esos expedientes, pues muestran la complejidad de las reformas, que si bien la historiografía mexicanista ha insistido en presentar como radicales y dramáticas para las cofradías, ${ }^{5}$ podemos ver en ellos de qué forma se articulaban las continuidades y los cambios, no menos que las dificultades para ejecutar de manera sistemática la reforma. Para mejor contextualizarlos, en primer lugar volveremos sobre la importancia que el culto eucarístico tenía para la catolicidad desde el siglo XVI, y las características principales de su instituto principal, el de las archicofradías del Santísimo Sacramento, para presentar enseguida las novedades que, dentro de esta misma tradición, trajeron consigo las congregaciones de cocheros y del

3 Los cocheros han sido estudiados por Clara GARCÍA AYLUARDO, "Ceremonia y cofradía: la Ciudad de México durante el siglo XVIII", en R-M. MEYER COSíO (coord.), Identidad y prácticas de los grupos de poder en México, siglos XVII-XIX. Seminario de formación de grupos y clases sociales, 1999, 71-72. A. LEMPÉRIÈRE, Entre Dieu et le Roi, La République. Mexico, XVI $I^{e}-X I X^{e}$ siècles, 2004, 180-181.

4 Hasta donde sabemos sólo ha sido estudiada en fecha reciente para México por Margaret CHOWNING, "La feminización de la piedad en México: Género y piedad en las cofradías de españoles. Tendencias coloniales y poscoloniales en los arzobispados de Michoacán y Guadalajara", en B. CONNAUGHTON (coord.), Religión, política e identidad en la Independencia de México, 2010, 484-486.

5 Especialmente: A. BAZARTE, Las cofradías de españoles en la ciudad de México (1582-1860), 1989, 129-138. A. BAZARTE y C. GARCÍA AYLUARDO, Los costos de la salvación: las cofradías y la ciudad de México (siglos XVI al XIX), 2001, 38-43. Clara GARCÍA AYLUARDO, "Re-formar la Iglesia novohispana", 262-271. alumbrado, dando cuenta, desde luego, de su difusión por el reino de la Nueva España.

Enseguida, trataremos de la importancia del culto eucarístico para los reformadores del siglo XVIII, tanto civiles como eclesiásticos, centrándonos en los motivos que hacían de él un culto útil, y en las dificultades que los fiscales de la Corona tuvieron para integrar en la reforma a sus innovaciones. En fin, un aspecto no menor de las cofradías del culto eucarístico en esta época es la importancia dada en ellas a la "distinción" de sus miembros. Es un tema fundamental para los propios congregantes, y del que veremos su relación con la devoción y la religiosidad, así también las reacciones de las autoridades civiles y eclesiásticas, a veces contradictorias, pues lo mismo podían criticar sus prácticas que integrarlas a sus proyectos.

En suma pues, la historia de estas cofradías, antiguas y nuevas dedicadas al culto de la Eucaristía, nos confirman hasta qué punto la Corona, con todo y los cambios en sus prioridades imperiales, y los empeños de clérigos y magistrados en separar lo sagrado de lo profano, no podía evitar la continuidad de su confusión, ni tampoco dejar de servirse de las corporaciones para la puesta en práctica de sus reformas.

\section{El Culto del SANTísimo SACRAMENTO}

El culto eucarístico constituye sin duda uno de los elementos fundamentales de la catolicidad desde el siglo XVI. No está de más recordarlo: frente a la Reforma protestante que ponía en cuestión la presencia real divina en el pan y el vino consagrados, el Concilio de Trento declaró directamente en 1551, que "se contiene en el saludable sacramento de la santa Eucaristía verdadera, real y substancialmente nuestro Señor Jesucristo". ${ }^{6}$ Por ello, a partir de entonces el espacio sagrado, el de las iglesias, estará centrado en el depósito eucarístico, el sagrario, que deberá encontrarse "decentemente" adornado y alumbrado de manera continua, y de preferencia en posición visible desde la puerta misma de las iglesias. Tal será una de las principales preocupaciones de los obispos en sus visitas por sus diócesis, verificar que el mayor número de iglesias posible cuente con la dignidad necesaria para albergar la presencia real en sus altares; que efectivamente los sagrarios, dorados y decorados, se encuentren en una posición central en ellos, y que en permanencia ardiera a su frente una lámpara de aceite. ${ }^{7}$

De ahí también que algunas grandes festividades públicas de la época queden, en todo el mundo católico, asociadas al culto eucarístico. Si bien existía ya desde siglos atrás, la fiesta de Corpus Christi adquirirá por ello renovada importancia y esplendor. En ella, en medio de los fastos más

6 Concilio de Trento, sesión XIII, Decreto sobre el Santísimo Sacramento de la Eucaristía, cap. I.

7 Sobre la importancia del Santísimo Sacramento en el espacio urbano véase: A. LEMPÉRIÈRE, Entre Dieu et le roi... 103-108. El tema de la organización del espacio sagrado ha sido poco tratado en la historiografía mexicanista, por lo cual remitimos a las orientaciones generales de B. CHÉDOZEAU, Chœur clos, chœur ouvert. De l'église médiévale à l'église tridentine (France, XVIIe-XVIIIe siècle), 1998. 
solemnes, con fanfarrias, repique de campanas, bajo de calles adornadas y otros despliegues barrocos, la Eucaristía sale anualmente por las calles a recorrer las ciudades, sacralizando sus espacios cotidianos, acompañada de todos los cuerpos urbanos, desde las más modestas cofradías hasta las más altas autoridades civiles y eclesiásticas, desfilando desde luego según sus correspondientes jerarquías. ${ }^{8}$ No menos importantes eran las fiestas de consagración de las nuevas iglesias, para las cuales se repetían en parte los esplendores del Corpus, procesionando las imágenes de los santos patronos a instalar en el nuevo templo, precediendo justamente a su residente principal, la Eucaristía. ${ }^{9}$ Por supuesto, el espacio público no veía sólo al Santísimo Sacramento para eventos festivos. Ante prácticamente cualquier calamidad pública, se hacía necesaria su exposición solemne o se organizaba una procesión de rogativa, a veces penitencial inclusive, todo ello no sólo por iniciativa de los clérigos sino en virtud a veces de los reclamos de algunos pueblos. ${ }^{10}$

Además de organizar el espacio sagrado y de manifestarse constantemente en el espacio público, el culto eucarístico se impondrá también como parte del modelo de vida ideal de la Reforma católica, el de los devotos, los seglares comprometidos con la renovación de la sociedad bajo los criterios de la catolicidad. Si la mayor parte de los fieles está obligada por mandamiento de la Iglesia a comulgar una vez al año, los devotos harán de este ejercicio una práctica semanal al menos, organizando por tanto sus jornadas en vista a dignificarse para un evento que no dejaba de ser extraordinario. ${ }^{11} \mathrm{Y}$ es justamente para difundir el modelo de los devotos de la Reforma católica que se da un nuevo impulso a las cofradías sacramentales.

Ya unos años antes de la apertura del Concilio Tridentino, el propio Papa Paulo III había dado un nuevo vigor al culto eucarístico de los fieles al otorgar, en 1539, diversos privilegios a la por entonces recién fundada cofradía del Santísimo Sacramento de la iglesia de Santa María de la Minerva de Roma. ${ }^{12}$ Lo ha destacado Marie-Hélène Froeschlé-Chopard, esta nueva cofradía era en parte heredera de las cofradías del Corpus Christi medievales, existentes desde el siglo XIII, pero respondía a nuevas exigencias, propias de la devoción de la Reforma católica. En efecto, se distingue por estar abierta a todos los fieles, sin importar sexo, edad o condición, constituyendo así un importante lugar de sociabilidad fundada en la religión; es responsable de importantes actos de culto en honor del Santísimo Sacramento, en particular,

\footnotetext{
8 Véase en particular A. MOLINIÉ-FIORAVANTI (coord.), Celebrando el Cuerpo de Dios, 1999.

9 Nos permitimos remitir a lo que hemos tratado sobre el tema con el ejemplo de la parroquia de Orizaba en D. CARBAJAL LÓPEZ, Utilité du public ou cause publique. Les corporations religieuses et les changements politiques à Orizaba (Mexique), 1700-1834, tesis doctoral, 2010, 86-88.

10 Alexis MEUNIER, “Nécessités publiques ou 'dévotion des peuples': Les polémiques autour de l'exposition fréquente du SaintSacrement", en B. DOMPNIER (dir.), Les cérémonies extraordinaires du catholicisme baroque, 2009, 63-78.

11 L. CHÂTELLIER, L'Europe des dévots, 1987, 48-53.

12 M. ROMERO SAMPER, Las cofradías en el Madrid del siglo XVIII 578-582.
}

su acompañamiento en la procesión de Corpus Christi y en una procesión semejante repetida una vez al mes, el tercer domingo de preferencia, la que será llamada la "procesión de Minerva". Es también receptora de numerosas gracias espirituales: las indulgencias, asimismo convertidas en símbolo de la catolicidad ante las críticas del protestantismo, comenzando por la indulgencia plenaria concedida a sus miembros en su ingreso a ella. Asimismo, su instituto comprende actos de piedad interior, como oraciones cotidianas y exámenes de conciencia, necesarios para la confesión y sobre todo la comunión frecuentes. En fin, desde sus inicios la nueva cofradía estaba destinada a expandirse hasta los confines de la catolicidad, pues recibió el carácter de "archicofradía", esto es, podía recibir agregaciones de otras a las que, aceptando su instituto, transmitiría sus mismos privilegios. ${ }^{13}$

$Y$ en efecto no tardó prácticamente nada en difundirse hasta lo que por entonces eran los confines de la catolicidad. La cofradía del Santísimo Sacramento de la ciudad de México, con sede en la iglesia de la Santísima Trinidad, obtuvo su agregación a la Minerva de Roma en fecha tan temprana como en 1540, gracias a las gestiones del clérigo Pedro de Paz. ${ }^{14}$ Convertida así en archicofradía, sus privilegios se fueron extendiendo a los pueblos de la arquidiócesis como prueba el caso de la sacramental de Tepotzotlán, fundada al menos desde 1583 y que contaba con un testimonio de la bula de la capitalina que estimaba como propia. ${ }^{15}$ Sus constituciones, redactadas inicialmente en 1615 , nos servirán a aquí para ilustrar el instituto de estas corporaciones. ${ }^{16}$

El culto eucarístico era particularmente constante a lo largo del año. Comprendía, como ya hemos dicho, una función mensual, el tercer domingo de mes, con misa, procesión "con candelas encendidas" por las naves de la iglesia parroquial y confesión general de los congregantes. Pero además de ese ritmo mensual, seguía todo el calendario litúrgico con sus momentos fuertes en la Semana Santa y en el Corpus. El Jueves Santo, con motivo de la conmemoración de la institución de la Eucaristía, los cofrades asistían a la misa, a la procesión "haciendo las penitencias a que les incline su devoción", encargándose del depósito del Santísimo en el monumento que se levantaba para su resguardo, velándolo por turnos "con hachas encendidas". Les correspondía organizar también la misa y procesión del Jueves de Corpus, acompañándola, no sólo con sus luces, sino también "con danzas y otras representaciones devotas".

En esas dos grandes festividades, comulgaban también, previa la confesión y examen de conciencia. Seguían además las principales festividades marianas del año: la Purificación ( 2 de febrero), la Anunciación (25 de marzo), la Asunción

13 M-H. FROESCHLÉ-CHOPARD, Espace et sacré en Provence (XVIeXXe siècle). Cultes, images, confréries, 1994, 509-518.

14 Sobre esta archicofradía A. BAZARTE, Las cofradías de españoles 141 y ss.

15 Archivo General de Indias (AGI), México, 2670, "Testimonio del expediente formado a pedimento del mayordomo, rector y demás oficiales de la cofradía del Santísimo Sacramento de la parroquia de Tepotzotlán, solicitando superior licencia para la recaudación de cornadillos de dicha cofradía", fs. 25v-37v.

16 Las constituciones en ibidem, fs. $9 v-16 v$, a que remitimos para lo siguiente. 
(15 de agosto), la Natividad de la Virgen (8 de septiembre) y la Inmaculada Concepción (8 de diciembre). En todas ellas, asistían a vísperas, misa y procesión con velas, ganando indulgencias confesándose y comulgando. En fin, de manera más cotidiana, era su deber también acompañar el viático, la hostia consagrada llevada a los enfermos y moribundos, "con luces", desde el anuncio de su salida de la iglesia parroquial hasta su retorno.

Como puede advertirse, el culto del Santísimo Sacramento se componía así, esencialmente de su acompañamiento, su iluminación y su recepción digna. La Majestad Divina, no podía presentarse en público sola, los cofrades estaban ahí justamente para garantizar que ese "espectáculo lamentable" no llegara a ocurrir. Pero no bastaba su presencia, fuera con hachas, con candelas o con velas, había que iluminar su paso y ello implicaba un gasto significativo en cera. $Y$ es que de la misma forma que en el Corpus Christi la hostia se presentaba en la custodia emulando el disco solar, la mejor manera de rendirle culto era alumbrándolo. De ahí que una de las preocupaciones más constantes de este instituto era reunir limosnas para ese fin: la sacramental de Tepotzotlán cuestaba para ello de manera semanal en la iglesia y en el mercado semanal (el tianguis). En fin, los hermanos debían comulgar por lo menos unas dieciocho veces al año, siendo que el común de los fieles, ya lo hemos dicho, estaba obligado a ello una sola vez.

Fue en el marco de las archicofradías que surgió, en primer término, el instituto de los cocheros del Santísimo Sacramento. Hasta donde sabemos, la primera de las congregaciones se formó en la ciudad de Veracruz, en abril de 1748 , justamente al interior de la archicofradía sacramental de la parroquia. ${ }^{17}$ Sesenta y dos de sus hermanos, encabezados por don Juan José Alegre, tomaron el título de Lacayos de Cristo Sacramentado, con el compromiso de turnarse y acompañar con dos hachas encendidas al viático en visita a los enfermos, además de las procesiones de Corpus. En concreto eran tres las novedades introducidas: en primer término, que el acompañamiento no era en procesión sino en el estribo de la estufa que conducía al sacerdote con el Sacramento, de ahí el término de "lacayos"; en segundo lugar, aunque no estaba explícitamente asentado en las constituciones, era claro que quedaba restringida a los varones capaces de dicho empleo; en fin, se obligaba a portar una insignia, que entonces debió ser más bien modesta pues no costaba más que 3 pesos. ${ }^{18}$ Años más tarde, sin que podamos precisarlo con exactitud, la insignia se transformó en librea, en este caso "colorada y blanca con ojales de plata en su guarnición", que habría de ser el distintivo fundamental del nuevo instituto.

Quince años más tarde, en 1763, el instituto comenzaría su exitosa difusión por las parroquias de la Ciudad de México, comenzando, según parece, por la de Santa Catalina mártir. ${ }^{19}$ Ésta, asumía algunas obligaciones más, siguiendo

17 AGI, Indiferente General, 191, "Testimonio de las diligencias practicadas sobre la pretensión de los lacayos del Santísimo Sacramento de Veracruz para usar librea".

18 Ibidem, fs. 8-16.

19 AGI, México, 2669, testimonio adjunto a la solicitud de la congregación. siempre el ejemplo de las cofradías sacramentales, por ejemplo el acompañamiento en los oficios de Jueves y Viernes Santo. Pero contrario a la de Veracruz surge distanciándose de la sacramental, que ya existía en la parroquia, e incluso de su párroco, que en algún momento declarará inclusive no reconocerla por congregación formal. Su instituto fundamental estaba siempre ligado a los turnos en la conducción del carruaje del viático, en este caso un forlón tirado por mulas, introduciendo además como novedad una terminología ad hoc para denominar sus cargos. Si la de Veracruz estaba gobernada originalmente por un tesorero, la primera de las congregaciones capitalinas lo era ya por un "cochero mayor". Asimismo, se preveía la posibilidad de salidas con mayor rango, que se distinguirían por los tiros largos del coche, y en las que el propio cochero mayor llevaría la conducción, dejando al de turno en calidad de sota. ${ }^{20}$

Por esas mismas fechas, pero con mayores dificultades, se organizaría la de la parroquia principal, la del Sagrario de la Catedral Metropolitana, que redactó sus constituciones bajo el nombre de "Compañía de Cocheros del Santísimo Viático" hasta 1777 . Éstas eran mucho más extensas y detalladas que las anteriores, innovando de nuevo en la terminología de los oficios: en lugar de mayordomo o tesorero había directamente un "caballerizo", pues los bienes principales de la corporación no eran sino los coches, caballos y mulas. Los turnos eran también más detallados hasta en el horario: de ocho a doce por las mañanas y de tres a nueve por las tardes, "sin que el agua ni la más cruel intemperie excuse su concurrencia". ${ }^{21}$ En cambio, no hay ya mención alguna respecto a portar cirios o hachas durante la conducción del viático, cosa que se repetirá en la compañía de la parroquia de Santa Veracruz, que claramente inspiró sus constituciones en las del Sagrario, redactándolas en 1789. ${ }^{22}$

En los años siguientes, hasta comienzos del siglo XIX, el instituto seguirá su expansión por al menos otras cuatro parroquias capitalinas: Santa María la Redonda (1791), San Pablo (1793), San Miguel (ca. 1789) y San Sebastián (ca. 1813). ${ }^{23}$ Pero también hubo iniciativas en el resto del reino, algunas no llegaron consolidarse, como la de Orizaba, donde hubo intentos para formarla en 1803 y en 1817, siempre considerando "el nulo acompañamiento" en que se veía el viático, "sin más guía que con la campanilla". ${ }^{24}$

Hacia el noroeste, la difusión del instituto de los cocheros alcanzó la villa de Lagos, en $1786,{ }^{25}$ y de Aguascalientes en 1797 , fecha en la cual una nueva congregación preten-

\footnotetext{
20 Ibídem, constituciones del 15 de enero de 1763.
}

21 AGI, México, 2686, "Testimonio del expediente formado sobre el establecimiento de una Congregación de Cocheros del Santísimo en el Sagrario de esta capital entre los caballeros de primera nobleza", fs. 5-13.

22 AGI, México, 2669, "Testimonio del expediente formado a solicitud de D. Manuel Pérez y consortes, vecinos de esta ciudad, sobre erigir una Congregación de Cocheros del Santísimo Sacramento en la parroquia de la Santa Veracruz de esta corte", fs. 3-5.

23 Sus expedientes en: AGI, México, 1301; AGI, México, 1309A, AGI, México, 2680 y AGI, México, 2702.

24 Archivo Notarial de Orizaba (ANO), Registro de Instrumentos Públicos (RIP), 1817, fs. 41-42, escritura de 18 de marzo de 1817.

25 R. FERNÁNDEZ SOTELO y M. MANTILLA TROLLE (eds.), La Nueva Galicia en el ocaso del Imperio español. Los Papeles de Derecho de la Audiencia de la Nueva Galicia del licenciado Juan José Ruiz Moscoso, su 
dió adoptar las constituciones de la erigida en la parroquia de Santa María la Redonda de México. ${ }^{26}$ Para ello hubo, sin embargo, un problema fundamental: la cofradía no se titulaba de cocheros del Santísimo, sino del Alumbrado y Vela, como lo hizo notar un escandalizado fiscal del Consejo de Indias en octubre de $1798 .^{27}$ En Aguascalientes pues, se habían entrecruzado, literalmente, las dos renovaciones del instituto del Santísimo Sacramento, lo que nos permite volver ahora sobre esta última, la del Alumbrado y Vela.

El nuevo instituto tenía uno de los más honrosos orígenes: la corte misma del rey Carlos IV. En enero de 1789, un grupo de cortesanos, encabezados por los marqueses de Santa Cruz y de Ariza, solicitó la aprobación de las constituciones, que fueron sancionadas en una real cédula de 28 de abril de ese mismo año, dirigida al cardenal de Sentmanat, patriarca de Indias y capellán mayor del rey, para establecerla en las iglesias de su jurisdicción, es decir, la capilla del palacio real, y diversas iglesias de los reales sitios, reales monasterios y hospitales..$^{28}$ El nuevo instituto era en realidad harto sencillo: consistía en dedicar media hora diaria a velar, es decir, a rezar ante el Santísimo Sacramento, mientras las iglesias estuviesen abiertas. En principio habría de gobernarse como cualquier otra hermandad, por una junta de oficiales encabezada por un hermano mayor, si bien su ocupación principal consistía en llevar el libro en que habrían de establecerse los turnos ante el Sagrario, desde luego cuidando por el cumplimiento de tales compromisos. ${ }^{29}$

Los cortesanos hicieron circular el nuevo instituto a los demás prelados del Imperio, incluyendo justamente a los de los reinos que le daban su título al Patriarca que los encabezaba, algunos de los cuales se mostraron celosos en su cumplimiento. Fue el caso del arzobispo de México, Alonso Núñez de Haro y Peralta, quien ya en 1791 se comprometía a emprender cuantos esfuerzos fueran necesarios para erigirlas en las iglesias de la arquidiócesis. Y en efecto, un año y medio más tarde, en marzo de 1793, el arzobispo informaba al rey que había logrado establecerla en la parroquia de San Sebastián, aunque no era primero, pues ya en 1792 el obispo de Santiago de Chile había informado también de su establecimiento. ${ }^{30}$

Así pues, el 11 de marzo de 1793 tuvo lugar la solemne función de inicio de la vela perpetua, "con exposición del Santísimo, misa y sermón" en la parroquial de San Sebastián. De nuevo, la difusión no se hizo esperar, haciéndose más fácil por contar con ejemplares impresos de las de Madrid. En Durango se estableció al menos desde el propio año de 1793; en Puebla, aunque no sabemos si se erigió como congregación, su instituto se estableció ya en 1796, y en Atlixco desde $1799 .{ }^{31}$ En Aguascalientes, una vez corregido el error

agente fiscal y regidor del Ayuntamiento de Guadalajara, 1780-1810, 2003, vol. II, pp. 52-53.

26 AGI, Guadalajara, 376.

27 Ibídem, dictamen del fiscal del Consejo, 25 de octubre de 1798.

28 Constituciones de la Real Congregación del Alumbrado y Vela del Santísimo Sacramento, 1790.

29 Ídem.

30 AGI, México, 1301, el arzobispo de México al rey, 30 de marzo de 1793, dictamen del fiscal del Consejo, 8 de enero de 1794.

31 Sabemos de ellas gracias a la Gazeta de México, t. V, núm. 54, 28 de septiembre de 1793, p. 526 para Durango; t. VIII, núm. 18, 17 de de los devotos de la Eucaristía, en 1803 insistieron en su establecimiento, ${ }^{32}$ utilizando ya las constituciones correctas, que sirvieron en 1804 para erigir la de Orizaba. ${ }^{33}$

Las innovaciones del instituto de las cofradías sacramentales no hacían sino poner énfasis en alguno de los aspectos de su culto, manteniendo una amplia continuidad con las prácticas de las corporaciones de las que estaban inspiradas. Con mayor énfasis en el acompañamiento, en las calles o en la iglesia respectivamente, no perdían por ello su carácter devocional ni dejaban de participar en otras varias funciones de iglesia. Continuadoras pues de las prácticas de la Reforma católica, todas estas archicofradías tradicionales, congregaciones de lacayos y cocheros del viático y del alumbrado y vela perpetua, debían haber sido por ello mismo tanto más sujetas a la reforma que en los finales del siglo XVIII emprendieron los magistrados de la Corona.

\section{LA REFORMA DE UN CULTO ÚTIL}

Al principio de este artículo evocamos la reforma de las cofradías en el Imperio hispánico. Conviene recordar que fue, en efecto, bajo el reinado de Carlos III, que comenzaron los esfuerzos en ese sentido, a través de expedientes generales y particulares en los principales tribunales regios. Mientras que en el Consejo de Castilla la reforma se llevó a cabo a través de un expediente general, abierto en 1768 a consecuencia de una representación del obispo de Ciudad Rodrigo, ${ }^{34}$ en el Consejo de Indias tuvo lugar sobre todo a partir de expedientes particulares. En principio, la reforma estaba dirigida a desplazar a las cofradías de la jurisdicción eclesiástica a la jurisdicción civil, a partir de un mismo fundamento legal: la legislación recopilada. En efecto, las leyes 3a y 4a a título XIV, libro 8‥ de la Nueva Recopilación de Leyes de Castilla y la ley 25, título IV, libro 10 de la Recopilación de Leyes de Indias, prohibían su fundación sin contar con la licencia del monarca, previa autorización de los obispos. Siendo que la gran mayoría de las cofradías del Imperio había sido fundada sin ese requisito, los fiscales y consejeros reales estimaban que era de su responsabilidad poner fin a esa "usurpación", como la calificaría el conde de Aranda. ${ }^{35}$ Cierto, los proyectos de los "ilustrados" iban más allá de la mera revalidación de las cofradías por las autoridades civiles, pero en la práctica fue ese justamente el procedimiento básico que se utilizó para su reforma.

En el caso peninsular, en virtud de una real resolución de 1783 , consecuencia del expediente general iniciado en 1768, comenzó la "recogida de constituciones", debiendo formarse juntas que examinarían esos documentos

septiembre de 1796, p. 141 para Puebla y t. IX, núm. 44, 29 de mayo de 1799, p. 345 para Atlixco.

32 AGI, Guadalajara, 576, representación del síndico de Aguascalientes, 6 de diciembre de 1803.

33 Archivo Histórico Parroquial del Sagrario de San Miguel Arcángel de Orizaba (AHPSSMAO), c. 189, "Libro de la Insigne y Real Congregación del Alumbrado y Vela del Santísimo Sacramento".

34 M. ROMERO SAMPER, Las cofradías en el Madrid, 123-126. I. ARIAS SAAVEDRA y M-L. LÓPEZ-GUADALUPE MUÑOZ, La represión de la religiosidad popular 229-352.

35 Citado en ibidem, p. 336. 
fundamentales, o bien lo harían los tribunales reales, las Audiencias y el Consejo de Castilla. ${ }^{36}$ En el Consejo de Indias, ya en 1767 pero sobre todo a partir de 1776, se dio nuevo vigor a la ley recopilada que citamos antes, por lo que más de un centenar de cofradías novohispanas acudió, desde esa fecha y hasta 1820, a obtener la confirmación de sus constituciones. ${ }^{37}$ Una diferencia importante entre las dos reformas, es que la del Consejo de Indias requirió en buena medida del apoyo del clero. La mayor parte de las corporaciones que se presentaron en Madrid lo hicieron obligadas por los autos de visita pastoral del arzobispo de México, Alonso Núñez de Haro y Peralta, quien les imponía término de dos años para obtener la licencia real. ${ }^{38}$ Pero además, el Consejo respetó siempre el tenor literal de la ley, que obligaba a que toda nueva redacción de constituciones pasara por la revisión del arzobispado, normalmente a través de su provisor previo dictamen del promotor fiscal, y si bien declaraba que la presidencia de los cabildos correspondía a un juez real, dejaba un papel importante al clero, que debía hacerse presente a través de los prelados de las iglesias correspondientes. ${ }^{39}$

Es por ello que los expedientes de reforma de las cofradías cuentan con una importante documentación generada por el propio clero, pues incluyen las diligencias hechas ante los promotores fiscales y provisores, a más de informes de los párrocos o superiores conventuales de las iglesias donde residían, o bien simplemente porque en muchas ocasiones eran clérigos quienes actuaban como representantes de esas corporaciones. Todos ellos son los primeros en defender la utilidad de las casi cuarenta cofradías y congregaciones sacramentales, tanto tradicionales como nuevas, cuyos expedientes Ilegaron al Consejo.

Entre los informes episcopales, los hubo que estuvieron limitados a destacar el aspecto religioso de la corporación. Así, el obispo de Michoacán, fray Antonio de San Miguel, tratando de la sacramental que estaba por restablecerse en Celaya en 1792, se limitó a destacar "la dignidad del objeto" a que se dirigía esta devoción, ${ }^{40}$ mientras que el provisor de México en 1799, elogiaba en la sacramental de Toluca el estar dedicada a "objetos enteramente piadosos". ${ }^{41}$ En cambio, el arzobispo Haro y Peralta subrayaba en sus informes otros aspectos que interesaban asimismo a los propios magistrados reformistas: las cofradías no sólo eran útiles para el culto sino también para los feligreses. En 1780, a propósito de la sacramental de San Juan Teotihuacán,

\footnotetext{
36 La real resolución de 25 de junio de 1783 en ibidem, 899-910.

37 Ya A. LEMPÉRIÈRE, Entre Dieu et le roi..., 177, había hecho notar el resultado de esos expedientes: las cédulas reales que en materia de cofradías llegaron en este período al gobierno de México.

${ }_{38}$ Al respecto: L. ZAHÍNO PEÑAFORT, Iglesia y sociedad en México, 1765-1800. Tradición, reforma y reacciones, 1996, 89-110; A. LEMPÉRIÈRE, Entre Dieu et le roi... 178-179 y C GARCÍA AYLUARDO, "EI privilegio de pertenecer".

${ }^{39}$ A diferencia de la Península, donde la presidencia por el juez real y la presencia de los párrocos no fueron impuestas de manera sistemática en la real resolución de 1783.

40 AGI, México, 2672, informe del obispo fray Antonio de San Miguel, Valladolid de Michoacán, 20 de julio de 1792.

41 AGI, México, 2651, "Testimonio del expediente rotulado: Sobre aprobación de las cofradías del Santísimo Sacramento y Benditas Ánimas del Purgatorio de la Iglesia parroquial de la ciudad de Toluca", fs. 3v-4.
}

decía directamente que estas corporaciones "son útiles a las parroquias y a los mismos cofrades". ${ }^{42}$ Por supuesto, se refería a su contribución "al mayor culto divino y beneficio espiritual de los fieles" por el pago de sus fiestas y misas, oficiadas normalmente en memoria de sus difuntos y por el bien de los propios vecinos, de las que garantizaba haberse velado siempre por su devoción por parte del clero. Mas insistió también en su carácter voluntario, es decir, que no eran impuestas por los párrocos ni constituían por tanto una carga a los fieles. En su informe sobre la cofradía sacramental de Tepotzotlán en 1791, el arzobispo agregaría además, que no sólo no eran gravosas, sino que los oficiales de ellas recibían un sueldo conforme al trabajo que desempeñaban. ${ }^{43}$

En otros momentos, el gobierno arzobispal destacaría también su dedicación a la caridad, como en la licencia concedida en 1798 a las constituciones de la sacramental de Santiago de Querétaro, en las que se destacaba sus auxilios para los pobres, tanto para sus entierros como para sus necesidades. ${ }^{44}$ En un tenor semejante, el provisor de Oaxaca, sobre la sacramental de Huajolotitlán en 1797, elogiaría que a más del "culto y devoción", sus constituciones se preocupaban por el "beneficio espiritual y temporal" de los hermanos asentados. ${ }^{45}$

Aunque los prelados no lo decían directamente, las cofradías sacramentales eran de utilidad al propio clero. Quien lo reconoció en cambio fue el párroco de Xochimilco, Tomás Domingo Moreno, informando a favor de la cofradía del pueblo de Tecomic en 1792. "Las misas de festividades y cofradías", afirmaba, junto con las obvenciones de sacramentos y entierros, eran lo único que formaba la congrua sustentación de los curas, de sus tenientes y vicarios, así como era el fondo para contribuir a las fábricas de las parroquias, desprovistas de diezmos. De ahí que fueran de necesidad "tan urgente como precisa". ${ }^{46}$ Además, bien consciente sin duda de las prioridades de la Corona en esta época, no dejó de advertir que gracias a sus fondos, las parroquias y las iglesias de los pueblos no estaban obligadas a recurrir a la Real Hacienda para sus gastos.

Cuando se trató de los nuevos institutos, el clero no tardó en advertir semejantes aspectos de utilidad, pero más que todo, los informes favorables a los Cocheros y al Alumbrado destacaban el "buen ejemplo" que daban a los demás fieles. Esta preocupación no era, desde luego, ninguna novedad en la catolicidad, antes bien todas las cofradías devotas, las órdenes terceras, no menos que las propias órdenes religiosas y congregaciones clericales, lo contaban también desde tiempo atrás entre los motivos para ser consideradas

42 AGI, México, 2664, informe del arzobispo de México, Alonso Núñez de Haro y Peralta, 20 de mayo de 1780.

43 AGI, México, 2670, informe del arzobispo de México, Alonso Núñez de Haro y Peralta, 1ㅇ de febrero de 1791.

44 AGI, México, 2672, "Testimonio del expediente sobre aprobación de las constituciones de la archicofradía del Santísimo Sacramento de la ciudad de Querétaro", fs. 43v-44v.

$45 \mathrm{AGI}$, México, 1317, "Testimonio del expediente rotulado: El Br. D. Francisco González, cura de Huazolotitlán, obispado de Oaxaca, sobre licencia para fundar en su doctrina una archicofradía del Santísimo Sacramento", fs. 13-16.

46 AGI, México, 1306, Tomás Domingo Moreno, cura de Xochimilco, al rey, 30 de marzo de 1792. 
útiles. ${ }^{47}$ Lo decían directamente el párroco de Santa Catalina mártir y el defensor de testamentos, capellanías y obras pías de la mitra de México en 1787, la nueva congregación de cocheros serviría de "buen ejemplo y edificación" a los fieles. ${ }^{48}$ Los párrocos del Sagrario Metropolitano, confirmando esa misma idea con mayor entusiasmo, señalaban además que gracias a ellos se aumentaría la frecuentación de la iglesia parroquial por los fieles y por tanto su contribución a las necesidades materiales de ella, por lo que era "en cierto modo necesaria a la decencia y decoro". ${ }^{49}$ Lo mismo aplicaba a la Congregación del Alumbrado. El arzobispo Haro y Peralta se había mostrado entusiasta de la iniciativa procedente de la Casa Real, pues con ella habría personas "que exciten al mayor culto y devoción del Santísimo". ${ }^{50}$

Volveremos más tarde sobre el buen ejemplo de los cofrades, pero toca ahora examinar los puntos de vista de los magistrados y fiscales de la Corona. Éstos, dentro de la amplitud de su crítica a las cofradías, no hacían tampoco generalizaciones radicales, sino que antes bien señalaban la importancia de algunas de ellas. Las sacramentales solían constituir una de esas excepciones a todos los niveles de su jerarquía, reconociendo su utilidad para el culto y para los fieles en su conjunto. Esto es, a pesar de que sin duda las prioridades de la Corona habían cambiado a lo largo del siglo XVIII, el culto divino por sí mismo podía seguir siendo "útil y necesario" en la perspectiva de los magistrados reales, compartida así con los clérigos de la época. La Monarquía seguía siendo católica, y debía por ello mismo proteger al que era el símbolo religioso por excelencia de la catolicidad, el Santísimo Sacramento.

El propio conde de Aranda, presidente del Consejo de Castilla durante la primera etapa de la reforma, decía claramente en un informe de 1773: "sólo merecen atenderse las sacramentales parroquiales", incluso "con su tasa correspondiente para el culto divino" pero "sin fiestas ni regocijos". ${ }^{51} \mathrm{En}$ un sentido semejante habían ido ya las respuestas de los intendentes y corregidores en los informes pedidos por el Consejo para el expediente general, valorando la "eficacia religiosa" de las sacramentales, al lado de las dedicadas a la devoción de las Benditas Ánimas del Purgatorio y de las caritativas. ${ }^{52}$

En el Consejo de Indias y en el gobierno del reino de la Nueva España, la situación no era distinta. Había en principio argumentos religiosos: la valoración del culto divino por sí mismo, pero al igual que lo hemos visto con el arzobispo Haro y Peralta, del beneficio espiritual de los fieles en su conjunto. Así, ya en 1779 , el fiscal Antonio Porlier tratando

\footnotetext{
47 Nos permitimos remitir al respecto a D. CARBAJAL LÓPEZ, Utilité du public..., 113-114.

48 AGI, México, 2669, "Testimonio del expediente instruido sobre fundar una congregación de cocheros españoles del Divinísimo Señor Sacramentado en la parroquia de Santa Catarina mártir de esta capital", fs. $38 v-48$.

49 AGI, México, 2686, "Testimonio del expediente formado sobre el establecimiento de una Congregación de Cocheros del Santísimo en e Sagrario de esta capital entre los caballeros de primera nobleza", f. 18v.

50 AGI, México, 1301, informe del arzobispo de México, Alonso Núñez de Haro y Peralta, México, 30 de marzo de 1793.

51 Citado en I. ARIAS SAAVEDRA y M-L. LÓPEZ-GUADALUPE MUÑOZ, La represión de la religiosidad popular 347.

52 Ibídem, 306-307.
}

del expediente de la sacramental del pueblo de Tizayuca, había declarado que, conforme al tenor estricto de la ley de Indias, "no puede subsistir", pero concedió sin embargo que debía de continuar en virtud de su dedicación al culto divino, y porque si desaparecía ello iría en "detrimento espiritual no sólo de los cofrades sino de los demás feligreses". 53 El argumento se repetiría en adelante con la mayor parte de las cofradías sacramentales, tratando por ello no de su extinción sino de la reforma de sus constituciones. Porlier, afirmará en 1786 que ellas "están recomendadas en todas partes", mientras que sus sucesores, Juan Antonio de Uruñuela, llegaría a calificar éste de un "piadoso y recomendable objeto", y Ramón de Posada de "instituto preciso para cualquier iglesia parroquial". ${ }^{54}$

Los virreyes no tuvieron tampoco mayor problema en apoyar en sus informes a las cofradías sacramentales: el virrey Martín de Mayorga en el expediente de la de Tulancingo, la juzgaba "útil y conveniente" al lado de la de Ánimas, "porque cede en justo obsequio del culto divino", idea que repetirán, poco más o menos, todos sus sucesores. En la Audiencia de México, los fiscales apoyarían su subsistencia fundados sobre todo en el argumento del perjuicio que su extinción acarrearía a los fieles: en la de Tepotzotlán, por ejemplo, Lorenzo Hernández de Alva hizo notar que sus fondos se quedarían sin destino y "los cofrades perderían el derecho adquirido" con sus limosnas. ${ }^{55}$

Mas el reconocimiento de su utilidad, no impediría a los fiscales del Consejo tomar medidas para verificar que fueran efectivamente necesarias y no un impulso del interés del clero, que era sin duda la diferencia fundamental entre ellos y los prelados. El fiscal Uruñuela mandaría por ejemplo pedir información al virrey respecto de la sacramental del pueblo de Tecomic, cuya solicitud era respaldada únicamente por el párroco de Xochimilco, "el cual no merece aprecio por el interés que se le sigue de que subsista este cuerpo", decía directamente el letrado. ${ }^{56}$ En el mismo sentido iría Ramón de Posada en 1796, mirando con incredulidad la solicitud del párroco de Huajolotitlán de fundar una cofradía sacramental, "por ser notorio que en los pueblos de indios no sólo hay regularmente congregaciones del Santísimo Sacramento sino muchas otras con diversos títulos". ${ }^{57}$

La reconocida utilidad tampoco obstaba para insistir en que estaban bajo la jurisdicción civil y no eclesiástica, como se advierte en los dictámenes de Uruñuela para el caso de

53 AGI, México, 1769, dictamen del fiscal del Consejo, 4 de agosto de 1779. Para los nombres de los fiscales del Consejo hemos seguido a G. BERNARD, Le secrétariat d'État et le Conseil Espagnol des Indes (17001808), 1972, 226-227.

54 AGI, México, 2670, dictamen del fiscal del Consejo, 4 de noviembre de 1786; dictamen del fiscal del Consejo, 20 de enero de 1791 y AGI, México, 2672, dictamen del fiscal del Consejo, 3 de noviembre de 1792.

55 AGI, México, 2664, informe del virrey Martín de Mayorga, 7 de octubre de 1780; AGI, México, 2670, "Testimonio del expediente formado a pedimento del mayordomo, rector y demás oficiales de la cofradía del Santísimo Sacramento de la parroquia de Tepotzotlán, solicitando superior licencia para la recaudación de cornadillos de dicha cofradía", fs. 41-42v.

56 AGI, México, 1306, dictamen del fiscal del Consejo, 8 de junio de 1791.

57 AGI, México, 1317, dictamen del fiscal del Consejo, 26 de marzo de 1796. 
las de Pachuca y Tlayacapan en 1792, evocando los "inconvenientes contra la tranquilidad pública" que se citaban en las leyes de Castilla, es decir, la formación de juntas clandestinas y de "partidos", que era el motivo para que sus cabildos fueran presididos por magistrados reales. ${ }^{58}$ Menos aún había razón para multiplicarlas indefinidamente como haría notar Posada en la solicitud de una para la Catedral de Durango, haciendo notar que si canónicamente no había obstáculo para ello, en lo civil "no hay decreto que permita su establecimiento en las iglesias donde ya le hubiere". ${ }^{59}$ Antes bien, Posada insistiría en que la sacramental, asociada normalmente a la de Ánimas, fuera la cofradía en que se refundieran las otras de una misma parroquia para reducir así su número, que como los demás fiscales de la época, no dejaba de considerar excesivo. ${ }^{60}$ En ello mismo habría de insistir su sucesor, Lorenzo Hernández de Alva, ${ }^{61}$ aunque en general el Consejo se mostró reticente para tomar medidas de este tipo.

Cuando se trató de las nuevas congregaciones de Cocheros y del Alumbrado, los fiscales las trataron en términos semejantes. Tocó a Porlier dictaminar en las primeras dos que se presentaron, la de la parroquia de Santa Catalina mártir de México y la de Veracruz, y como se trataba de nuevo del culto sacramental, no dudo en decir que era un "fin espiritual, piadoso y recomendable" y además "loable, ejemplar y edificativo", concediendo por ello mismo la subsistencia de una y otra. ${ }^{62}$ Pero ya el fiscal Uruñuela, en 1790, al revisar el expediente de la de Santa Catalina y recibir el de la parroquia de Santa Veracruz, se dio cuenta de que se trataba de un instituto distinto y paralelo al de las tradicionales archicofradías sacramentales, y más aún, que comenzaba a difundirse por la capital, aumentando el número de cofradías, que justamente se trataba de reducir. Por ello, sin dejar de repetir que se trataba de "un acto de laudable edificación y ejemplo", y fundado en que "el excesivo número de congregaciones suele ocasionar gravísimos inconvenientes trascendentales al público, y en su consecuencia al Estado", prefirió dejar al Consejo la decisión sobre su licencia. ${ }^{63}$ Éste, a su vez, la dejó en manos del virrey, mas el conde de Revillagigedo dio trámite a la real cédula como si se hubiera tratado de una autorización para fundarla, sin que el dictamen de Uruñuela, que iba adjunto, llamara la atención ni del fiscal ni del asesor del gobierno. ${ }^{64}$

58 AGI, México, 2671, dictámenes del fiscal del Consejo, 27 de junio de 1792.

59 AGI, Guadalajara, 376, dictamen del fiscal del Consejo, 26 de agosto de 1796.

${ }^{60}$ AGI, México, 2651, dictamen del fiscal del Consejo, 16 de octubre de 1796. AGI, México, 2647, dictamen del fiscal del Consejo, 1ㅇ de marzo de 1797. AGI, México, 2672, dictamen del fiscal del Consejo, 24 de octubre de 1799 .

${ }_{61} \mathrm{AGI}$, México, 2680, dictamen del fiscal del Consejo, 30 de junio de 1803.

62 AGI, México, 2669, dictamen del fiscal del Consejo, 27 de noviembre de 1785 . AGI, Indiferente General, 191, dictamen del fiscal del Consejo, 20 de mayo de 1787.

63 AGI, México, 2669, dictamen del fiscal del Consejo, 3 de octubre de 1790.

${ }_{64}$ AGI, México, 2672, "Testimonio del expediente formado a instancia de D. Manuel Pérez y consortes, vecinos de esta ciudad, sobre erigir una Congregación de cocheros del Santísimo Sacramento en la parroquia de la Santa Veracruz de esta corte", fs. 1-10v.
Con ello, el antecedente que temía el fiscal quedó bien asentado, y las siguientes corporaciones no tuvieron mayor problema en obtener su licencia hasta que el 2 de febrero de 1796, el fiscal Ramón de Posada notó de nuevo que estas corporaciones se estaban extendiendo por varias parroquias de la capital. Así, de alguna forma esquivaban las medidas que se habían ido tomando para tratar de reducirlas a sólo la sacramental y la de Ánimas. No sin cierto escándalo, el letrado señalaba que "el prurito de fundar otras y otras, ya con estos títulos, ya con aquellos es increíble", por lo que fue de dictamen se diera cuenta primero si ya había una cofradía sacramental en la parroquia, la de San Pablo de México. ${ }^{65}$ Empero, su intento resultó vano, pues el Consejo, lejos de conformarse con su parecer, aprobó la nueva congregación el 9 de marzo siguiente, y los últimos fiscales del tribunal, fundados en semejantes precedentes, continuaron aprobándolas.

El caso de la congregación del Alumbrado y Vela revela más aún las contradicciones de la reforma de las cofradías. El Consejo de Indias se entera de la primera fundación, la de la parroquia de San Sebastián, cuando ya ha sido erigida por el arzobispo de México. Éste, había recibido la real cédula y constituciones de la congregación directamente de manos del marqués de Santa Cruz, sin pasar por el Consejo, y siguiendo lo determinado en ella, estaba por completo bajo la jurisdicción eclesiástica (así como la de Madrid estaba bajo la tutela del Patriarca de Indias) y sus bienes declarados exentos. En consecuencia, en enero de 1794 se enviaron instrucciones al virrey para que la congregación se uniformara al menos con las prevenciones generales dadas a las otras cofradías que se habían ido reformando, mas casi cinco años después, en noviembre de 1798, todavía se esperaba alguna respuesta. ${ }^{66}$ Mayor escándalo causó al fiscal Posada saber, en este último año, que de la misma forma se había erigido también la de Aguascalientes, y más aún que había recibido la aprobación tanto del provisor como de la Audiencia de Guadalajara, siendo que la real cédula, emitida por la Cámara de Castilla, ni siquiera les había sido dirigida de manera particular y antes bien, los ministros reales tendrían que haber impedido su cumplimiento como no emitida por el Consejo de Indias. ${ }^{67}$

La reforma, se veía presa de una de sus contradicciones: la valoración que los propios fiscales, consejeros y cortesanos hacían del culto al Santísimo Sacramento, abría la puerta a que no sólo las archicofradías tradicionales buscaran su aprobación, sino a que justamente estas nuevas iniciativas se sirvieran de ella para obtenerla también. A pesar de la oposición de los fiscales más estrictos, como Ramón de Posada, cocheros y congregantes del alumbrado, verían así confirmado su carácter de "útiles y necesarios" tanto para la jurisdicción eclesiástica como para la civil.

A más de ello, los expedientes nos revelan otro aspecto de estas cofradías, el de la relevancia que en estos finales del siglo XVIII, adquiría la "distinción" en la sociedad novohispana.

65 AGI, México, 1309A, dictamen del fiscal del Consejo, 2 de febrero de 1796.

66 El expediente en AGI, México, 1301

67 AGI, Guadalajara, 376. 


\section{CULTO Y DISTINCIÓN}

El culto del Santísimo Sacramento nunca estuvo desprovisto de un cierto lucimiento de las jerarquías profanas: las varas del palio de la procesión de Corpus solían ser reservadas a los regidores de las villas y ciudades, mientras que las demás autoridades y magistrados de la monarquía iban detrás del preste; además, en el mundo hispánico, la llave del sagrario donde quedaba reservada la Eucaristía el Jueves Santo solía ser confiada a alguna autoridad civil de alto rango. ${ }^{68}$ La devoción eucarística de los monarcas fue asimismo proverbial, no faltando a ella Carlos III, célebre por dejar su carruaje para arrodillarse al paso del viático y seguir su acompañamiento. ${ }^{69}$ La verdadera novedad que representaban los nuevos institutos de congregaciones eucarísticas que surgen en esta época estaba justamente en la importancia, todavía mayor, que otorgaban al "lustre" o a la "distinción", asociado desde luego a la trascendencia del culto al que se dedicaban, y que debía ser visible exteriormente en los trajes y en la nobleza de sus miembros.

Tan es así que la primera de las congregaciones de cocheros de que tenemos noticia, la de Veracruz, no se presentó ante el Consejo de Indias en 1782 para pedir la confirmación de sus constituciones, sino para obtener licencia para el uso de una "moderada librea", que ya habíamos evocado antes. Ya en 1785, la congregación aprovechó los trámites al respecto para modificar sus constituciones, incluyendo ahora una cláusula restrictiva para el ingreso de nuevos hermanos, que deberían ser españoles y con "empleo decente en la república", mientras que los oficiales habrían de ser "sujetos beneméritos". La librea se perfeccionó también entonces, para quedar compuesta de "casaca y calzones colorados, vuelta y chupín blanco, éste guarnecido de galón de oro angosto, y botones de lo mismo". En fin, los congregantes reclamaron tres privilegios más, uno para su fiesta titular, la del Corazón de María, eligiendo "a la persona más condecorada y de mayor graduación” para llevar el guión en la procesión, y dos relacionados con el Santísimo Sacramento: en la salida del viático, el derecho exclusivo para la "honrosa comisión" de abrir y cerrar la puerta de la estufa al preste, y el Jueves Santo, el de nombrar un custodio de la llave del sagrario, teniéndola por su oficio el tesorero de la corporación. ${ }^{70}$

Por su parte, en 1763, la congregación de la parroquia de Santa Catalina había elegido una librea semejante, pero con botas blancas y dragona de plata. Además, se introdujo la práctica de hacer del viático a los congregantes

68 Además de la obra ya citada de A. MOLINIÉ-FIORAVANTI (coord.), Celebrando el Cuerpo de Dios, 1999, véase J. VALENZUELA MÁRQUEZ, Las liturgias del poder. Celebraciones públicas y estrategias persuasivas en Chile colonial (1609-1709), 2001, 178-180. Más generalmente A. CABANTOUS, Entre fêtes et clochers. Profane et sacré dans l'Europe moderne, XVII ${ }^{e}$-XVIII ${ }^{e}$ siècle, 2001, 38-44.

69 W. CALLAHAN, Iglesia, poder y sociedad en España, 1750-1874, 1989, 14-15. "Devoto rayano en la superstición” dice sobre él F. SÁNCHEZ BLANCO, El absolutismo y las Luces en el reinado de Carlos III, 2002, 45 $y$ en general 40-59.

70 AGI, Indiferente general, 191, "Testimonio de las diligencias practicadas sobre la pretensión de los Lacayos del Santísimo Sacramento de la ciudad de Veracruz para usar librea", fs. 10-35v. prácticamente una procesión de gala por sí misma, acompañada de "una música decente" y al menos cuarenta luces, que aumentaban si se trataba de sacerdotes o de oficiales y sus esposas. ${ }^{71}$ Tratándose además de la decana de las congregaciones capitalinas, uno de sus fundadores, don José Carrillo, habría de pretender en 1799 , el título "a lo menos en lo honorífico" de "cochero mayor de todas", con una librea particular que lo diera a entender. ${ }^{72}$

Si la de Santa Catalina aumentaba en honores, la congregación de la parroquia del Sagrario lucía en cambio la distinción de sus miembros, quienes debían ser "sujetos visibles de conducta, hidalguía y limpieza [de sangre]". Y en efecto, entre los primeros oficiales se contaban a varios títulos de Castilla, como los marqueses de Valle Ameno y de Torrecampo, los condes de Santiago y de Presa de Jalpa, y el mariscal de Castilla. Para ser oficial además, no podían elegirse personas "que haya contraído infamia pública o secreta", quedando a la cabeza de la corporación, como su "jefe y gobernador" el propio virrey, frey Antonio María de Bucareli, y sus sucesores. ${ }^{73}$

Las siguientes congregaciones capitalinas continuaron la misma línea, tanto respecto de los criterios de admisión como en las celebraciones, y sobre todo en la elección de libreas y de divisas. Si la congregación de Aguascalientes mantuvo todavía el tradicional rojo con blanco en $1797,{ }^{74}$ incluso estos colores se irían modificando en las capitalinas. Así, la congregación de la parroquia de San Pablo diseñó la suya sustituyendo el chupín blanco por uno azul, ${ }^{75}$ la de Santa Veracruz prefirió el color rojo, ${ }^{76}$ y la de San Sebastián, que fue la que más cambios introdujo, optó por casaca azul con vuelta y collarín en rojo y centro blanco, diseño que le traería una amarga disputa con los escribanos del gobierno del reino por el estrecho parecido con su uniforme. ${ }^{77}$ Esta misma congregación había también perfeccionado la procesión del viático a los cocheros enfermos. El Sacramento iría bajo de palio, precedido por todos los congregantes con luces y seguido de la estufa, tirada por cuatro mulas y guiada por el cochero mayor con el de turno como sota; precaviendo las distancias, se establecía que si había que salir de la jurisdicción parroquial, la primera parte del camino

71 AGI, México, 2669, testimonio adjunto a la solicitud de 20 de septiembre de 1785 .

72 AGI, México, 2676, solicitud de D. José Carillo, 17 de agosto de 1799

73 AGI, México, 2686, "Testimonio del expediente formado sobre el establecimiento de una Congregación de Cocheros del Santísimo en el Sagrario de esta capital entre los caballeros de primera nobleza", fs. 5-13.

74 AGI, Guadalajara, 376, testimonio anexo a la solicitud de 14 de agosto de 1798.

75 AGI, México, 1309A, "Constituciones de la congregación de cocheros y criados del Augusto Sacramento de la parroquia de San Pablo de México".

76 AGI, México, 2669, "Testimonio del expediente formado a solicitud de D. Manuel Pérez y consortes, vecinos de esta ciudad, sobre erigir una Congregación de Cocheros del Santísimo Sacramento en la parroquia de la Santa Veracruz de esta corte", fs. 3-5.

77 AGI, México, 2702, "Testimonio del expediente promovido por el cochero mayor de los distinguidos del Santísimo de la Parroquia de San Sebastián, sobre aprobación de sus constituciones". 
la hiciera el preste en la estufa, pero habría de bajarse al menos dos cuadras antes de llegar a la casa del enfermo. ${ }^{78}$

El establecimiento del Alumbrado del Santísimo Sacramento tenía en común la preocupación por la calidad de sus miembros y oficiales, habiendo estado originalmente reservada a los criados de la Casa Real, fundadores del instituto en Madrid, los cuales seguían el ejemplo de los propios monarcas Carlos IV y María Luisa de Parma, quienes acudían a orar ante la Eucaristía en algún momento de la jornada. ${ }^{79}$ El arzobispo Haro y Peralta recurrió por ello a la nobleza capitalina para cubrir los primeros cargos: el vice hermano mayor era el mariscal de Castilla, conciliarios los condes de Medina y Torres y de la Cortina junto con el superintendente de la Casa de Moneda y un cónsul de la corporación de comerciantes, ambos caballeros de la orden de Carlos III, y así sucesivamente. Ellos habrían de solicitar a su vez la intermediación del prelado para obtener que los monarcas fuesen hermano y hermana mayor perpetuos de la corporación. ${ }^{80}$

En los otros puntos del reino, si bien no alcanzaría el mismo abolengo que en la capital, su difusión se dio efectivamente a través de las élites locales. Lo hacía notar el Diario de México en 1807: a ejemplo de los nobles reunidos en San Sebastián, "se han fundado en otros lugares con las instrucciones que han pedido los principales vecinos de ellos". ${ }^{81}$ Así, en Aguascalientes su principal impulsor fue don Juan José Cayetano Ruiz de Esparza, miembro de una de las principales familias de hacendados presentes en el ayuntamiento local. ${ }^{82}$ En Orizaba, donde la congregación se estableció en 1804, reuniría también a los notables, los cosecheros de tabaco y comerciantes, siendo su primer hermano mayor José Salazar y Cortázar, poco después subdelegado, al lado de familias como los Montes Argüelles, Bringas de Manzaneda, De la Llave, Portas, Escandón y otras presentes asimismo entre los regidores perpetuos y alcaldes de la villa. ${ }^{83}$

Ahora bien, al momento de examinar sus constituciones y solicitudes, las autoridades civiles y eclesiásticas tuvieron reacciones diversas ante la insistencia de estas nuevas congregaciones en todos estos honores y distinciones. En el caso de la primera de ellas, la de Veracruz, el tema más controvertido fue sin duda el de su posesión de la llave del depósito del Jueves Santo y su entrega a alguno de los notables locales. Ello constituía una de las mezclas entre lo más sagrado (la presencia real divina en la Eucaristía) y lo profano (las jerarquías sociales), que el clero de la época se esforzaba por limitar. Lo notó ya el provisor de la mitra de Puebla, la llave debía permanecer en manos del clero "por las repetidas declaraciones de la Sagrada Congregación de Ritos", que había calificado "cualquiera costumbre

78 Ídem.

79 Constituciones de la Real Congregación del Alumbrado, 1790.

80 AGI, México, 1301, el arzobispo de México al rey, 30 de marzo de 1793.

81 Diario de México, t. 7, núm. 713, 12 de septiembre de 1807, 47-48, el subrayado es nuestro.

82 Véase: B. ROJAS, Las instituciones de gobierno y la élite local. Aguascalientes desde el siglo XVII hasta la independencia, 1998.

${ }_{83}$ Nos permitimos remitir nuevamente a D. CARBAJAL LÓPEZ, Utilité du public ou cause publique, 198. en contrario como corruptela". ${ }^{84}$ El letrado terminó sin embargo por conceder la subsistencia de dicha costumbre, que fue también vista con desconfianza en el gobierno de México, donde tanto el fiscal de lo civil Lorenzo Hernández de Alva como el Real Acuerdo de la Audiencia advirtieron que en ese derecho debían predominar los magistrados civiles, el gobernador de Veracruz y los alcaldes de dicha ciudad en este caso. ${ }^{85}$ En Madrid, el fiscal Uruñuela fue más radical, repitiendo en parte lo que ya había dictaminado la jurisdicción eclesiástica: "es un puro abuso y corruptela", por lo que pidió su total supresión. Otro tanto sucedió, sin que el Consejo abundara en explicaciones, con el artículo que daba a la congregación un lugar de honor en las procesiones y en la puerta de la estufa del viático. ${ }^{86}$

Cierto, los clérigos no solían tener demasiados problemas con el tema de sus libreas y selectividad en el ingreso. Al contrario, el provisor del arzobispado de México, tratando sobre la de Santa Catalina mártir, aseguró que no sólo eran ya una forma de aumentar el culto, sino también una manera de proteger la custodia del Santísimo Sacramento de las "irreverencias" de los demás cocheros "que generalmente son de la ínfima plebe, y por lo regular dedicados al vergonzoso vicio de la embriaguez" ${ }^{87}$ Ya lo hemos indicado, el clero insistió en el tema del buen ejemplo que las "personas decentes" o "de distinción", debían dar a los demás fieles. Lo dijeron con especial claridad los párrocos del Sagrario metropolitano en 1778: el pueblo "se edifica" al ver al Santísimo Sacramento servido "en un ejercicio de sí mismo el más abatido, [a] aquellos que ve distinguirse entre los demás y señalarse por su nobleza o por su empleo". ${ }^{88}$ El promotor fiscal del arzobispado declaraba "edificarse" él mismo ante "el ahínco, devoción y constancia de la nobleza de México" en esta nueva congregación. ${ }^{89}$

Los fiscales de la Audiencia de México, por su parte, solían preocuparse por cómo determinar en la práctica los criterios de distinción sin caer en disputas interminables, como solía temerse en general de las cofradías. El fiscal Alva impuso por ello en la de Santa Catalina mártir que toda admisión habría de resolverse por el mayor número de sufragios. ${ }^{90}$ Por motivos semejantes, ya a principios del

84 AGI, Indiferente general, 191, "Testimonio de las diligencias practicadas sobre la pretensión de los lacayos del Santísimo Sacramento de Veracruz para nueva librea", fs. 7v-8.

85 Ibídem, extracto del expediente.

86 Ibídem, dictamen del fiscal del Consejo, 29 de abril de 1789 y resolución del Consejo, 11 de mayo de 1789.

87 AGI, México, 2669, "Testimonio del expediente instruido sobre fundar una congregación de cocheros españoles del Divinísimo Señor Sacramentado en la parroquia de Santa Catarina mártir de esta capital", fs. $47 v-48$.

88 AGI, México, 2686, "Testimonio del expediente formado sobre el establecimiento de una Congregación de Cocheros del Santísimo en el Sagrario de esta capital entre los caballeros de primera nobleza", fs. 16-16v.

89 AGI, México, 2686, "Testimonio del expediente roturado el Lic. D. José María Santelices sobre aprobación de los estatutos de la congregación de cocheros del Santísimo Sacramento del Sagrario de esta Santa Iglesia matriz", f. 10v.

90 AGI, México, 2669, "Testimonio del expediente instruido sobre fundar una congregación de cocheros españoles del Divinísimo Señor Sacramentado en la parroquia de Santa Catarina mártir de esta capital", fs. 58-69v. 
siglo XIX, en la de la parroquia de San Sebastián, habría de tomarse la precaución de cambiar su título de "caballeros cocheros" por el de "distinguidos cocheros" para evitar confusiones en cuanto a su estatus..$^{91}$ Por lo que toca a las libreas, hubo algún esfuerzo puntual por moderar su uso: a consecuencia de su conflicto con los escribanos del gobierno del reino, a los de la parroquia de San Sebastián se les impuso en 1817 que debían usarla sólo durante las ceremonias y no de manera cotidiana y a todas horas. ${ }^{92}$ Mas en general, los fiscales de la Audiencia y los virreyes dieron la bienvenida a estas distinciones. Lo ha señalado ya Annick Lempérière, sus libreas y su carácter reservado contribuían justamente a los proyectos de reforma de la policía urbana de la época, favorables a ordenar la sociedad haciendo visibles sus rangos y sus cuerpos, y educando a la "plebe", en particular en materia de la "desnudez", combatida especialmente por los virreyes Revillagigedo y Branciforte..$^{93}$

Empero, ello no quiere decir que se construyera en esta materia una clara alianza entre las élites capitalinas y la Corona, como sugiere Clara García Ayluardo. ${ }^{94}$ Las congregaciones de cocheros recibieron también críticas fundadas en otro de los proyectos de reforma, el de la purificación de las prácticas religiosas. De hecho, fue sin duda en el Consejo de Indias donde los cocheros encontraron a su crítico más importante en la persona del fiscal Ramón de Posada. En 1794, él habría de negar el uso de sus uniformes a los militares que entraran en la congregación de la parroquia del Sagrario; en 1796, criticaba el "repique de campanas, libreas, uniforme, dragonas, competencias por precedencias" que reclamaban los de la parroquia de San Pablo, cuya licencia dictaminó debía concederse sólo de manera condicional, y en 1799, habría de responder a la petición de José Carrillo para obtener una librea propia de cochero mayor fundador, que su mérito "no pide recompensa de uniformes y títulos de esta especie". ${ }^{95}$ Posada se mostraba así un celoso custodio de una religiosidad ilustrada, interiorista y poco proclive a los fastos. Él mismo advertía que el Santísimo Sacramento había estado bastante bien servido con las archicofradías tradicionales, y que lejos de todas las pretensiones de las nuevas congregaciones, bastaba tributarle "el verdadero culto de sencillez, silencio y compunción". ${ }^{96}$

Las que en cambio podían reunir la aprobación unánime de los actores involucrados fueron sin duda las congregaciones del Alumbrado y Vela, en las que prácticamente las élites contribuían a difundir uno de los modelos de cofradía deseado por los ilustrados de la época. En efecto, su instituto cumplía con las exigencias tanto de clérigos como de fiscales reformadores, pues estaba reducido a una práctica

91 AGI, México, 2702, "Testimonio del expediente promovido por el cochero mayor de los distinguidos del Santísimo de la Parroquia de San Sebastián, sobre aprobación de sus constituciones".

92 Ibídem.

93 A. LEMPÉRIÈRE, Entre Dieu et le roi..., 180-181.

94 C. GARCÍA AYLUARDO, "Ceremonia y cofradía ", 71-72.

$95 \mathrm{AGI}, \mathrm{México}, 2686$, dictamen del fiscal del Consejo, 18 de enero de 1794; AGI, México, 1309A, dictamen del fiscal del Consejo, 2 de febrero de 1796; AGI, México, 2676, dictamen del fiscal del Consejo, 20 de noviembre de 1799.

96 AGI, México, 1309A, dictamen del fiscal del Consejo, 2 de febrero de 1796. interior, elogiada ampliamente en el sermón predicado en su establecimiento en la parroquia de San Sebastián. ${ }^{97}$ Otro punto a su favor, ante el "catolicismo ilustrado" era que no exigía tampoco cuotas de ingreso, sino que recogía sólo la limosna voluntariamente ofrecida por los fieles. Más aún, sus oraciones estaban dirigidas en particular a fines "útiles", como la salud de los reyes y la felicidad de la monarquía. ${ }^{98}$ Convertidos así en modelos de comportamiento para los fieles, los notables locales reunidos en estas congregaciones, eran prueba de que al menos en estas reformas tocantes a materias religiosas, los proyectos de la Corona no podían pasarse de las corporaciones para su puesta en marcha.

\section{COMENTARIOS FINALES}

El caso de las cofradías sacramentales y sus nuevos institutos, nos recuerdan hasta qué punto la reforma de los Borbones enlazaba con una tradición ya existente al interior de la catolicidad, que situaba a la presencia real divina en la Eucaristía en un posición tan alta, que su culto no podía sino ser considerado útil por sí mismo, incluso para los "ilustrados" de la época. Además, nos permiten resaltar los puntos en común con los proyectos de los clérigos, coincidentes no sólo en el valor del culto eucarístico y en la protección de lo sagrado y su separación de lo profano, sino también en su importancia para la subsistencia de las parroquias y para atender las necesidades de los fieles. Asimismo, lo hemos hecho notar, dan cuenta de las contradicciones internas en los afanes reformistas, entre por ejemplo el deseo de purificar el culto de los fastos profanos, y la importancia dada a la visibilidad y el orden de las jerarquías sociales, mostrándonos en fin, algunos de los límites de esos proyectos en profundidad y en extensión.

Pero además, estas archicofradías y congregaciones constituyen una prueba de que los Borbones, lejos de emprender la destrucción de las cofradías novohispanas, legaron al siglo XIX una generación renovada de ellas. En efecto, no sólo permanecieron las archicofradías tradicionales, las cofradías de cocheros, aprobadas y reformadas en medio de las contradicciones que hemos hecho notar, siguieron recorriendo las urbes otrora novohispanas en sus carruajes, luciendo sus libreas y transportando el sagrado viático, en varios casos hasta al menos la época de la Reforma liberal, dejando su huella en la memoria de las ciudades. Lo señaló en su tiempo Manuel Romero de Terreros para la de la parroquia del Sagrario de México, ${ }^{99}$ siendo el caso también de la de Guadalajara y la de Orizaba. En esta última, el cronista local José María Naredo, recordaba a finales del siglo xIX, con particular nostalgia, su participación escoltando con faroles adornados la procesión de Corpus Christi. ${ }^{100}$ Asimismo, el elitista instituto de la vela perpetua estaría destinado a popularizarse a lo largo del

97 Véase: C. HERREJÓN PEREDO, Del sermón al discurso cívico. México, 1760-1834, 2003, 243-245.

98 Constituciones de la Real Congregación del Alumbrado, 1790.

99 M. ROMERO DE TERREROS, Bocetos de la vida social en la Nueva España, 1944, 142-145.

100 J-M. NAREDO, Estudio Geográfico, Histórico y Estadístico del Cantón y de la Ciudad de Orizaba, 1898, 51. 
siglo siguiente, y más aún, a "feminizarse" en cierta medida. Lo ha estudiado ya Margaret Chowning, quien ha mostrado su importancia en la renovada participación de las mujeres en las nuevas asociaciones católicas del siglo XIX, particularmente en el occidente de México. ${ }^{101}$

Sin duda se requieren más estudios sobre las cofradías del primer siglo XIX mexicano. Mas el caso de Orizaba, que es el que menos desconocemos, donde la congregación del Alumbrado mantuvo un firme vigor frente a la decadencia de las demás cofradías tradicionales de la parroquia, ${ }^{102}$ nos deja imaginar al menos que estos institutos de finales del siglo XVIII, preocupados por la utilidad del culto, por la devoción interior y la distinción social, respondían bien a las inquietudes religiosas de las élites de la transición entre el Antiguo Régimen y el primer liberalismo.

\section{BIBLIOGRAFÍA Y REFERENCIAS}

\section{Archivos}

AGI, Archivo General de Indias.

AHPSSMAO, Archivo Histórico Parroquial del Sagrario de San Miguel Arcángel de Orizaba.

\section{Periódicos}

Gazeta de México, 1795-1799

Diario de México, 1807.

\section{BiBLIOgRAFíA}

Arias Saavedra, I y López-Guadalupe Muñoz, M-L. 2002. La represión de la religiosidad popular. Crítica y acción contra las cofradías en la España del siglo XVIII. Granada: Universidad de Granada.

Bazarte, A. 1989. Las cofradías de españoles en la ciudad de México (1582-1860). México: Universidad Autónoma Metropolitana-Azcapotzalco.

Bazarte, A. y García Ayluardo, C. 2001. Los costos de la salvación: las cofradías y la ciudad de México (siglos XVI al $X I X)$. México: Centro de Investigación y Docencia Económica/ Instituto Politécnico Nacional/ Archivo General de la Nación.

Cabantous, A. 2001. Entre fêtes et clochers. Profane et sacré dans l'Europe moderne, XVII ${ }^{e}-X V I I I^{e}$ siècle, París: Fayard.

Callahan, W. 1989. Iglesia, poder y sociedad en España, 1750-1874. Madrid: Nerea.

Carbajal López, D. 2010. Utilité du public ou cause publique. Les corporations religieuses et les changements politiques à Orizaba (Mexique), 1700-1834, tesis doctoral. París: Universidad París I Panthéon-Sorbonne.

Châtelier, L. 1987. L'Europe des dévots. París: Flamarion.

\footnotetext{
101 M. CHOWNING, "La feminización de la piedad en México"

102 D. CARBAJAL LÓPEZ, Utilité du public ou cause publique, 199-200.
}

Chédozeau, B. 1998. Chœur clos, chœur ouvert. De l'église médiévale à l'église tridentine (France, XVII ${ }^{e}-\mathrm{XVIII}{ }^{e}$ siècle). París: Les Éditions du Cerf.

Chowning, M. 2010. "La feminización de la piedad en México: Género y piedad en las cofradías de españoles. Tendencias coloniales y poscoloniales en los arzobispados de Michoacán y Guadalajara", en B. Connaughton (coord.). Religión, política e identidad en la Independencia de México. México: Universidad Autónoma Metropolitana/ Benemérita Universidad Autónoma de Puebla.

Fernández Sotelo, R. y Mantilla Trolle, M. (eds.), 2008. La Nueva Galicia en el ocaso del Imperio español. Los Papeles de Derecho de la Audiencia de la Nueva Galicia del licenciado Juan José Ruiz Moscoso, su agente fiscal y regidor del Ayuntamiento de Guadalajara, 1780-1810. Zamora: El Colegio de Michoacán/ Universidad de Guadalajara.

Froeschlé-Chopard, M-H. 1994. Espace et sacré en Provence (XVIe-XXe siècle). Cultes, images, confréries. París: Les Éditions du Cerf.

Herrejón Peredo, C. 2003. Del sermón al discurso cívico. México, 1760-1834. Zamora: El Colegio de Michoacán/ El Colegio de México.

García Ayluardo, C. 1999. "Ceremonia y cofradía: la Ciudad de México durante el siglo XVIII", en R-M. Meyer Cosío (coord.). Identidad y prácticas de los grupos de poder en México, siglos XVII-XIX. Seminario de formación de grupos y clases sociales. México: Instituto Nacional de Antropología e Historia.

García Ayluardo, C. 2007. "El privilegio de pertenecer: Las comunidades de fieles y la crisis de la monarquía católica", en B. Rojas (coord.), Cuerpo político y pluralidad de derechos. Los privilegios de las corporaciones novohispanas. México: Instituto de Investigaciones Dr. José María Luis Mora.

García Ayluardo, C. 2010. "Re-formar la Iglesia novohispana”, en C. García Ayluardo (coord.), Las reformas borbónicas. 1750-1808. México: Centro de Investigación y Docencia Económica/ Fondo de Cultura Económica/ Consejo Nacional para la Cultura y las Artes/ Instituto Nacional de Estudios Históricos de las Revoluciones de México/ Fundación Cultural de la Ciudad de México.

Lempérière, A.2004. Entre Dieu et le Roi, La République. Mexico, $X V l^{e}-X I X^{e}$ siècles. París: Le Belles Letres.

Meunier, A. 2009. “Nécessités publiques ou 'dévotion des peuples': Les polémiques autour de l'exposition fréquente du Saint-Sacrement", en B. Dompnier (dir.), Les cérémonies extraordinaires du catholicisme baroque. Clermont-Ferrand: Presses de l'Université Blaise-Pascal.

Molinié-Fioravanti, A. (coord.) 1999. Celebrando el Cuerpo de Dios. Lima: Pontificia Universidad Católica del Perú.

Naredo, J-M. 1898. Estudio Geográfico, Histórico y Estadístico del Cantón y de la Ciudad de Orizaba. Orizaba: Imprenta del Hospicio.

Rojas, B. 1998. Las instituciones de gobierno y la élite local. Aguascalientes desde el siglo xvII hasta la independencia. Zamora: El Colegio de Michoacán/ Instituto Mora. 
Romero de Terreros, M. 1944. Bocetos de la vida social en la Nueva España. México: Porrúa.

Romero Samper, M. 1998. Las cofradías en el Madrid del siglo XVIII, tesis doctoral. Madrid: Universidad Complutense de Madrid.

Sánchez Blanco, F. 2002. El absolutismo y las Luces en el reinado de Carlos III. Madrid: Marcial Pons.
Valenzuela Márquez, J. 2001. Las liturgias del poder. Celebraciones públicas y estrategias persuasivas en Chile colonial (1609-1709). Santiago de Chile: Centro de Investigaciones Diego Barrios Arana/ Lom Editores.

Zahíno Peñafort, L. 1996. Iglesia y sociedad en México, 1765-1800. Tradición, reforma y reacciones. México: Universidad Nacional Autónoma de Mëxico-Instituto de Investigaciones Jurídicas. 